\title{
Potent antilisterial cell-free supernatants produced by complex red-smear cheese microbial consortia
}

\author{
A. Bleicher, ${ }^{*}$ T. Stark,† T. Hofmann,† B. Bogovič Matijašić,‡ I. Rogelj,‡ S. Scherer, ${ }^{\circledR}$ and K. Neuhaus ${ }^{* 1}$ \\ ${ }^{*}$ Abteilung für Mikrobiologie, ZIEL, and \\ †Lehrstuhl für Lebensmittelchemie und Molekulare Sensorik, Wissenschaftszentrum Weihenstephan, Technische Universität München, \\ D-85354 Freising, Germany \\ ‡Dairy Science, Biotechnical Faculty, University of Ljubljana, SI-1230 Domžale, Slovenia \\ §Lehrstuhl für Mikrobielle Ökologie, Department für Grundlagen der Biowissenschaften, WZW, Technische Universität München, D-85350 \\ Freising, Germany
}

\section{ABSTRACT}

The microbial surface ripening consortia of 49 soft cheeses were investigated with respect to their inhibition of Listeria monocytogenes. When L. monocytogenes EGDe (serovar 1/2a) was cultivated in cell-free supernatants obtained from consortia grown for $8 \mathrm{~h}$ in liquid medium, a strong bactericidal activity was observed in several cases. The cell-free supernatants of 2 of these consortia (I and II) reduced an initial L. monocytogenes inoculum of $5 \times 10^{7} \mathrm{cfu} / \mathrm{mL}$ to zero after $24 \mathrm{~h}$ of incubation. No inhibitory substances could be washed off the complex consortia when incubated for a 10-min period. A taxonomical analysis of the antilisterial consortia I and II using Fourier transform infrared spectroscopy yielded a considerable species diversity, with lactic acid bacteria increasing strongly during the 8-h cultivation. Therefore, 23 lactic acid bacteria bacteriocin genes were assayed using specific PCR primers, identifying 3 bacteriocin genes in both microbial communities. However, no transcription of these genes was found on cheese surfaces or in consortia propagated in liquid culture. Individual lactic acid bacteria isolates of consortia I and II displayed no or only weak inhibition of L. monocytogenes on solid medium. The complex cell-free supernatants I and II, in contrast, exhibited an unusually broad inhibitory spectrum, killing L. monocytogenes ssp., Bacillus spp., Staphylococcus aureus, as well as gram-negative bacteria such as Escherichia coli DH5 $\alpha$ and Salmonella enterica serovar Typhimurium. Inhibition could not be abolished by heating to $100^{\circ} \mathrm{C}$ or by proteinase $\mathrm{K}$ treatment. Initial purification of an inhibitory substance from consortium I by solid-phase extraction and HPLC indicates the presence of rather small, extremely stable compounds, which, most probably, are not bacteriocins.

Received March 9, 2010

Accepted June 24, 2010

${ }^{1}$ Corresponding author: neuhaus@wzw.tum.de
Key words: Listeria monocytogenes, red-smear cheese, inhibition, cell-free supernatant

\section{INTRODUCTION}

Listeria monocytogenes, the causative agent of human listeriosis, is a gram-positive, non-sporeforming bacterium characterized by a remarkable resistance to environmental stresses (Low and Donachie, 1997). Its psychrophilic, acid-tolerant and halotolerant, facultatively anaerobic character allows the pathogen to overcome many common approaches of food preservation. The pathogenicity of $L$. monocytogenes is characterized by a switch from a saprophytic to an intracellular lifestyle. Its ability to spread from cell to cell and thus avoid the host's humoral immunity response may result in systemic infections (Freitag et al., 2009). The incidence of listeriosis in Europe is low, but the mortality rate can reach 25 to $30 \%$ among persons developing disease (de Valk et al., 2005).

The food-borne nature of $L$. monocytogenes was not recognized before the 1980s, when several listeriosis outbreaks were linked to the consumption of contaminated soft cheeses (Farber and Peterkin, 1991). The ripening parameters of salty red-smear cheeses at temperatures ranging from 14 to $19^{\circ} \mathrm{C}$ and a relative humidity of at least $95 \%$ provide excellent growth conditions for undesirable microorganisms. The practice of "old-young-smearing," i.e., the transfer of complex microbial consortia from ripe to fresh cheeses, further complicates the control of Listeria. As a consequence, smear cheeses are more frequently contaminated with $L$. monocytogenes than other soft cheeses, showing exceedingly high cell counts in some products (Jacquet et al., 1993; Loncarevic et al., 1995; Rudolf and Scherer, 2001). Undefined cheesesurface consortia with antilisterial properties have been described in the past, sometimes containing bacteria producing bacteriocins (Valdes-Stauber and Scherer, 1994; Saubusse et al., 2007). Bacteriocins are small, ribosomally synthesized peptides often acting on the 
cytoplasmic membrane of target bacteria, thereby causing dissipation of the proton motive force, leakage of small molecules, and subsequent cell lysis (for review, see Jack et al., 1995; Cotter et al., 2005). These findings raised hope that indigenous smear bacteria may serve as protective cultures to improve the hygienic quality of these products (McAuliffe et al., 1999; O'Sullivan et al., 2006). Some approaches pursued a strategy of external microbial protection using bacteriocinogenic starter cultures when the intrinsic protection of a product was inadequate (Eppert et al., 1997; Loessner et al., 2003).

However, the application of single inhibitory strains is limited because they have to compete with the resident, often very stable house flora of a certain ripening cellar (Feurer et al., 2004; Goerges et al., 2008). It has been shown that the addition of starter cultures to an established microbial consortium may not result in the expression of the desired functions that the pure cultures displayed. The present study, therefore, focuses on the antagonistic properties of the complex ripening flora. Our aims were i) to develop a testing system to identify antilisterial cheese-surface consortia, ii) to analyze their microbial composition in terms of species composition and diversity, and iii) to characterize the substances produced by the complex microbial populations.

\section{MATERIALS AND METHODS}

\section{Collection of Microbial Consortia}

Forty-nine smear cheeses produced in France, Italy, and Germany were bought on the retail market or provided by Unité de Recherches Fromagères (INRA, Aurillac, France). The surface flora was recovered using a sterile knife and homogenized in saline solution containing $5 \% \mathrm{NaCl}$ using a Stomacher Lab Blender (Seward Ltd, Worthing, UK). Suspensions were centrifuged at $6,600 \times g$ for $25 \mathrm{~min}$ at $4^{\circ} \mathrm{C}$ and washed twice in saline solution to remove excessive cheese fat. After addition of glycerol to a final concentration of $15 \%$ and thorough mixing, aliquots of $2 \mathrm{~mL}$ each were frozen at $-80^{\circ} \mathrm{C}$ (glycerol culture). All samples underwent routine analysis according to DIN EN ISO 11290-1 (2006) to detect natural contamination with Listeria sp.

\section{Supernatant Preparation}

Five hundred microliters of the glycerol culture was used to inoculate $15 \mathrm{~mL}$ of plate count broth supplemented with $3 \%$ sodium chloride (PC3+ broth) to adjust for the salty conditions of cheese brines (ValdesStauber et al., 1991). The flasks were incubated for 10 min or $8 \mathrm{~h}$ at $30^{\circ} \mathrm{C}$ with shaking $(180 \mathrm{rpm})$. The cells were pelleted by centrifugation at $12,000 \times g$ for $10 \mathrm{~min}$ at $4^{\circ} \mathrm{C}$. The supernatants were filter sterilized (Millex GP 0.2- $\mu \mathrm{m}$ filter units, Millipore, Schwalbach, Germany) and stored at $-20^{\circ} \mathrm{C}$ until use. The preparation of cell-free supernatants (CFS) was carried out at least 3 times independently. The $\mathrm{pH}$ was measured after thawing using universal indicator strips (Macherey-Nagel, Düren, Germany); the contents of lactic acid and hydrogen peroxide were determined using the analytical systems of Merck (Darmstadt, Germany). The enzymes lactate dehydrogenase and peroxidase, respectively, are immobilized on strips allowing quantification via a colorimetric reaction. Bacteriophage involvement was excluded by monitoring plaque formation on Listeria in poured plates using tryptic soy softagar $(17.0 \mathrm{~g} / \mathrm{L}$ of tryptone, $6.0 \mathrm{~g} / \mathrm{L}$ of yeast extract, $3.0 \mathrm{~g} / \mathrm{L}$ of soy peptone, $5.0 \mathrm{~g} / \mathrm{L}$ of NaCl, $2.5 \mathrm{~g} / \mathrm{L}$ of D-glucose, $2.5 \mathrm{~g} / \mathrm{L}$ of $\mathrm{K}_{2} \mathrm{HPO}_{4}$, and $7.5 \mathrm{~g} / \mathrm{L}$ of agar-agar).

\section{Cultivation Assay for Detection of Antilisterial Activity}

In the cultivation assay, L. monocytogenes EGDe (serovar $1 / 2 \mathrm{a}$ ) was grown overnight in brain heart infusion broth (Merck) and inoculated 1:20 in PC3+ broth. After $2 \mathrm{~h}$ of incubation, cells were diluted to obtain a cell density of $5 \times 10^{8} \mathrm{cfu} / \mathrm{mL}$. Five milliliters of the 49 CFS was inoculated with $0.5 \mathrm{~mL}$ of the Listeria suspension and incubated for $24 \mathrm{~h}$ at $30^{\circ} \mathrm{C}$ and $180 \mathrm{rpm}$. Samples of $100 \mu \mathrm{L}$ were serially diluted and plated onto PC3+ agar in duplicate. Viable cells of the indicator strain were counted after $2 \mathrm{~d}$ of aerobic incubation at $30^{\circ} \mathrm{C}$. Bacteriostatic activity was assumed when Listeria was not able to proliferate in the CFS but did not die; bactericidal activity was defined as a reduction of the initial inoculum of at least $2 \log$ units.

\section{Initial Characterization of Antilisterial Substances}

Consortia I and II, representing 2 different Munster cheeses, displayed a high inhibitory capacity among 8 antagonistic CFS. The complex CFS I and II were characterized further using $1 \times 10^{3} \mathrm{cfu} / \mathrm{mL} L$. monocytogenes EGDe. Both CFS were exposed to $100^{\circ} \mathrm{C}$ for $1 \mathrm{~min}$ and to $121^{\circ} \mathrm{C}$ for $15 \mathrm{~min}$ before inoculation. Proteinase $\mathrm{K}$ was added in a final concentration of $0.5 \mathrm{mg} /$ $\mathrm{mL}\left(30 \mathrm{U} / \mathrm{mg}\right.$, Merck) and incubated for $2 \mathrm{~h}$ at $50^{\circ} \mathrm{C}$. The enzyme was heat inactivated for $30 \mathrm{~min}$ at $75^{\circ} \mathrm{C}$. Catalase treatment was performed for $2.5 \mathrm{~h}$ at $37^{\circ} \mathrm{C}$ using a final concentration of $1 \mathrm{mg} / \mathrm{mL}(3,800 \mathrm{U} / \mathrm{mg}$, Sigma-Aldrich, Hamburg, Germany). In a combined approach, proteinase $\mathrm{K}$ was added after the reaction of catalase was completed. Both CFS were subjected to serial 2-fold dilutions up to 1:16 in PC3+ broth. The inhibitory spectrum was determined in a cultiva- 
tion assay (see above) using $1 \times 10^{3} \mathrm{cfu} / \mathrm{mL}$ each of the alternative indicator strains listed in Supplemental Table S1 (http://www.journalofdairyscience.org/). All experiments were conducted at least twice.

\section{Isolation of Inhibitory Lactic Acid Bacteria}

Eight-hour liquid cultures of consortia I and II were plated onto All Purpose Tween 80 agar plates (Merck) and incubated for $2 \mathrm{~d}$ at $34^{\circ} \mathrm{C}$ in an anaerobic jar containing the catalyst Anaerocult IS (Merck). Several hundred lactic acid bacteria (LAB) were randomly picked and transferred to new All Purpose Tween 80 agar plates. A 2-d period for the production of inhibitory substances under anaerobic conditions was given. Overnight cultures of the indicator strains listed in Supplemental Table S1 were used to inoculate tryptic soy softagar at 1:100. Ten milliliters of the seeded softagar was poured over agar plates containing picks or streaks of the LAB (overlay assay). After an overnight incubation at $30^{\circ} \mathrm{C}$ under aerobic conditions, antagonistic acting colonies were identified on the basis of clearing zones they caused in the confluent lawn of the indicator strains. Inhibitory strains were recovered from the plates, streaked to demonstrate purity, and applied to the assay a second time.

\section{Biodiversity Analysis by Fourier Transform Infrared Spectroscopy}

The composition of both the original and the 8-h propagated consortia I and II were studied in detail using Fourier transform infrared spectroscopy. One hundred bacterial colonies were picked randomly from PC3+ agar plates after 3 to $5 \mathrm{~d}$ of aerobic incubation at $30^{\circ} \mathrm{C}$. Lactic acid bacteria were cultivated anaerobically on All Purpose Tween 80 agar at $34^{\circ} \mathrm{C}$ (see above). The sample preparation to obtain reliable infrared spectra was carried out as described (Kümmerle et al., 1998; Oberreuter et al., 2002). For identification purposes, the spectra recorded were compared with a reference database made up of spectra of known strains grown under the same conditions as above. Two independent measurements were conducted using an HTS-XT Fourier transform infrared spectrometer (Bruker, Karlsruhe, Germany). For data processing, OPUS software version 6 (Bruker) was used. The spectral distances of the isolates, reflecting the similarity of 2 spectra by comparing the size of nonoverlapping areas, were used to discriminate the isolates at strain level. Cluster analysis was performed using the average linkage algorithm (Tindall et al., 2000), visualizing the abundance ratio of strains in a dendrogram.

\section{PCR Detection of Bacteriocin Encoding Genes}

Genomic DNA of consortia I and II was extracted according to the Rotiphenol protocol (Roth, Karlsruhe, Germany), following the recommendations of the manufacturer. Five hundred microliters of glycerol culture was mixed with $1 \mathrm{~mL}$ of Rotiphenol. After proteinase $\mathrm{K}$ treatment for digestion of disturbing proteins, the enzyme was heat inactivated. The PCR were performed using specific primer pairs for 23 different bacteriocin genes, listed in Supplemental Table S2 (http://www. journalofdairyscience.org/; oligonucleotide primers purchased from Invitrogen, Karlsruhe, Germany). The PCR amplification was carried out in a $50-\mu \mathrm{L}$ reaction mixture containing $1 \mathrm{pmol}$ of specific primers, 200 $\mu M$ deoxynucleotide triphosphates mixture (Thermo Scientific, Hamburg, Germany), $1.5 \mathrm{mM} \mathrm{MgCl} 2,1 \mathrm{U}$ of Thermoprime Plus Polymerase (Thermo Scientific), and $100 \mathrm{ng}$ of template. The PCR conditions were as described recently (see Supplemental Table S2). The DNA extracts of bacteriocin-producing strains, listed in Supplemental Table S1, served as positive controls. Amplified fragments were resolved by electrophoresis on $2 \%$ agarose gels and visualized by staining with ethidium bromide. Resulting bands were excised and sequenced for verification.

\section{RNA Extraction and Reverse Transcription}

Total RNA of consortia I and II was extracted directly from the thawed consortium using Trizol (Invitrogen), following the instructions of the manufacturer. Reverse transcription was performed on extracts standardized to $1 \mu \mathrm{g}$ of RNA by spectroscopic measurements at $260 \mathrm{~nm}$ (Nanodrop ND-1000, Peqlab, Erlangen, Germany). The reaction volume of $20 \mu \mathrm{L}$ contained DNase digested RNA (TURBO DNase, Ambion, Darmstadt, Germany), $500 \mu M$ dNTP mixture, $5 \mathrm{~m} M$ dithiothreitol (Invitrogen), $40 \mathrm{U}$ of RNase OUT (Invitrogen), and first strand buffer. One picomole of reverse primers (specific for lactococcin $\mathrm{G}$, helveticin $\mathrm{J}$, curvacin $\mathrm{A}$, acidocin $\mathrm{B}$, and cytolysin) was added for specific reverse transcription. Samples were completed by the addition of 200 U of Superscript III (Invitrogen); in blank samples no enzyme was added. The incubation conditions for the reverse transcription reaction were as follows: $25^{\circ} \mathrm{C}$ for $5 \mathrm{~min}, 50^{\circ} \mathrm{C}$ for $90 \mathrm{~min}$, and $70^{\circ} \mathrm{C}$ for $15 \mathrm{~min}$. The amplification reactions using cDNA as template were carried out as described for the genomic DNA samples. No PCR amplification could be achieved when RNA samples did not undergo reverse transcription (blank samples) or when water was added instead of template (blind samples). 


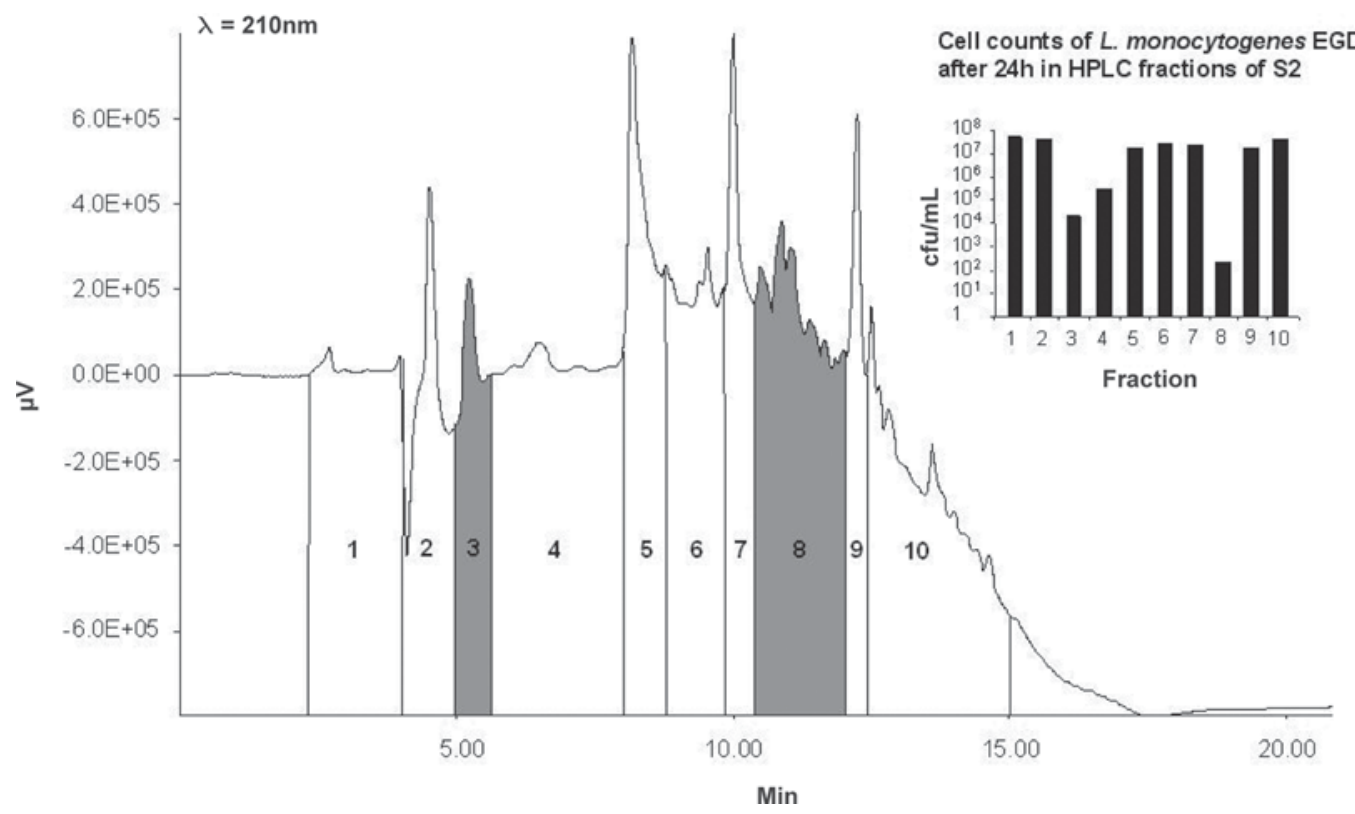

Figure 1. High performance liquid chromatography run of solid-phase extraction fraction eluted with 20\% methanol (S2). Fraction 8 (H8) showed the greatest bioactivity in the cultivation assay, reducing $1 \times 10^{3} \mathrm{cfu} / \mathrm{mL}$ of Listeria monocytogenes EGDe to $2 \times 10^{2}$ cfu/mL after 24 $\mathrm{h}$ of incubation.

\section{Fractionation of Complex Supernatant I by Solid-Phase Extraction}

Aliquots (2.5 mL each) of CFS I were applied onto the top of a C18- SPE (solid-phase extraction) cartridge (6 mL, 1 g, Strata C18-E, Phenomenex, Aschaffenburg, Germany) preconditioned with methanol, followed by water. Water for chromatographic separations was purified with a Milli-Q Gradient A10 system (Millipore), and solvents used were of HPLC grade (Merck). Fractionation was performed by flushing the column with water $(6 \mathrm{~mL}$, fraction $\mathrm{S} 1)$, followed by increasing methanol/water mixtures starting with a mixture of $20 \%$ (20/80, vol/vol; $6 \mathrm{~mL}$; fraction S2) in 20\% steps (S3-S5, $6 \mathrm{~mL}$ each), and methanol $(10 \mathrm{~mL}$; fraction $\mathrm{S} 6)$. The fractions $\mathrm{S} 1$ through $\mathrm{S} 6$ were concentrated in a vacuum $\left(40^{\circ} \mathrm{C}\right)$ and, after freeze-drying, resuspended in $1 \mathrm{~mL}$ of water. Bioactivity of individual fractions was determined in the cultivation assay.

\section{HPLC of CFS I: Separation of SPE Fractions S2 and S3}

Fractions active against $L$. monocytogenes EGDe were suspended in $1 \mathrm{~mL}$ of water, and aliquots $(250 \mu \mathrm{L})$ were separated by means of semipreparative HPLC. The HPLC system consisted of an HPLC pump system PU 2087; a high-pressure gradient unit; and a PU-2075 UV detector using a semipreparative reversed-phase (RP) column, Luna Phenyl Hexyl, $10.0 \times 250 \mathrm{~mm}$,
$5 \mu \mathrm{m}$ (Phenomenex, Aschaffenburg, Germany), as the stationary phase. Monitoring the effluent at $210 \mathrm{~nm}$, chromatography was performed starting with aqueous formic acid $(0.1 \%)$ for $3 \mathrm{~min}$, increasing the methanol content to $100 \%$ over $10 \mathrm{~min}$, and, thereafter, eluting with methanol for $5 \mathrm{~min}$ at a flow rate of $4.2 \mathrm{~mL} /$ min. After removing the solvent in vacuum, $40^{\circ} \mathrm{C}, 10$ subfractions each of S2 and S3 (S2/H1-H10 and S3/ H1-H10, respectively; Figure 1) were suspended in 10 $\mathrm{mL}$ of water and freeze-dried to determine the bioactivity of the individual fractions (see above).

\section{RESULTS AND DISCUSSION}

\section{Antilisterial Substances Are Produced in Short-Time Liquid Cultures}

Microbial cheese ripening consortia were suspended in PC3+ broth and incubated for a 10-min period to prepare complex supernatants. If antilisterial substances are already present in the consortium, they should be washed off the cells. However, no antilisterial effect was detected in these supernatants. In contrast, growth of Listeria was often stimulated and reached levels of 3 $\times 10^{9} \mathrm{cfu} / \mathrm{mL}$ (growth in PC3+ broth reached $1 \times 10^{9}$ $\mathrm{cfu} / \mathrm{mL}$ ). This difference was possibly due to the glycerol added to the consortia for storage. It is concluded that, in the microbial consortia directly isolated from cheeses, no or only negligible amounts of antagonistic substances are present, which can be washed off the 


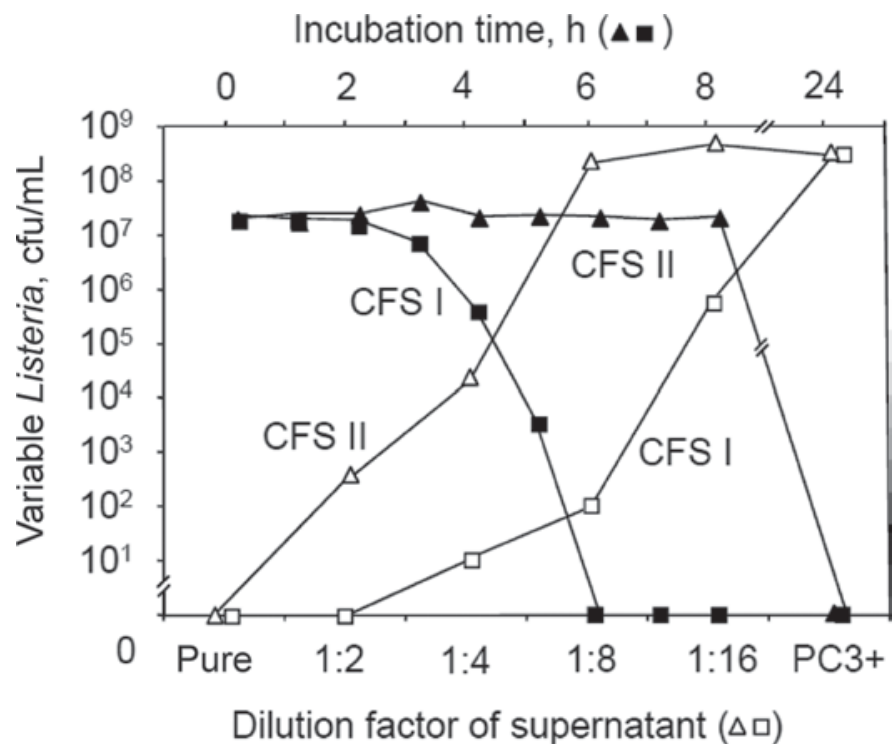

Figure 2. Effect of cell-free culture supernatants (CFS) from consortium I (squares) and consortium II (triangles). Two different experiments are shown. 1) Filled symbols: $10^{7} \mathrm{cfu} / \mathrm{mL}$ of Listeria monocytogenes EGDe was inoculated in each CFS and sampled every hour. 2) Open symbols: $10^{3} \mathrm{cfu} / \mathrm{mL}$ of $L$. monocytogenes was inoculated in serial 2-fold dilutions of each CFS and sampled once after $24 \mathrm{~h}$. PC3+ $=$ plate count broth supplemented with $3 \%$ sodium chloride.

cells. Therefore, a longer incubation period of $8 \mathrm{~h}$ at a high initial cell density (approximately $3 \times 10^{8} \mathrm{cfu} /$ $\mathrm{mL}$ ) was applied. A high initial cell density was chosen to trigger the production of antagonistic substances, which might be linked to quorum-sensing signaling cascades (Kleerebezem, 2004; Navarro et al., 2008). The incubation was performed at $30^{\circ} \mathrm{C}$ to fit most physiological groups constituting a cheese ripening consortium, enabling greater metabolic rates. When $5 \times 10^{7}$ $\mathrm{cfu} / \mathrm{mL}$ of L. monocytogenes EGDe (serovar 1/2a) was inoculated in 8-h CFS, 8 of 49 supernatants displayed a bactericidal effect, sometimes reducing the inoculated L. monocytogenes to zero after $24 \mathrm{~h}$, and 5 CFS acted bacteriostatically. The strongly inhibitory supernatants from consortia I and II, 2 different Munster cheeses from the French retail market, were chosen for further studies. Both CFS had a content of lactic acid of 4.4 $\mathrm{m} M$ and a content of $\mathrm{H}_{2} \mathrm{O}_{2}$ of less than $15 \mu M ; \mathrm{pH}$ values were 6.0 . The minimal inhibitory concentration of $\mathrm{H}_{2} \mathrm{O}_{2}$ in L. monocytogenes lies between 0.26 and $2.2 \mathrm{~m} M$ (Romanova et al., 2002); the minimal inhibitory concentration of lactic acid has been determined to be around $220 \mathrm{~m} M$ at refrigeration temperatures (González-Fandos and Dominguez, 2006). Obviously, the actively growing consortia, in which at the same time a biodiversity shift took place (see below), produced soluble antilisterial substances other than lactic acid or hydrogen peroxide.
Table 1. Characteristics of supernatants I and II and viable cell counts after $24 \mathrm{~h}$ when $10^{3} \mathrm{cfu} / \mathrm{mL}$ of Listeria monocytogenes EGDe was cultured in untreated, heat-treated, and enzyme-treated cell-free supernatants $(\mathrm{CFS})^{1}$

\begin{tabular}{lll}
\hline & \multicolumn{2}{c}{$\begin{array}{c}\text { Viable L. monocytogenes EGDe } \\
\text { after 24 h of incubation in }\end{array}$} \\
\cline { 2 - 3 } Characteristic & CFS I & CFS II \\
or treatment of CFS & 0 & 0 \\
\hline Untreated & 0 & $1.1 \times 10^{4}$ \\
1 min at $100^{\circ} \mathrm{C}$ & $1.8 \times 10^{3}$ & $2.3 \times 10^{6}$ \\
15 min at $121^{\circ} \mathrm{C}$ & 0 & $9.0 \times 10^{2}$ \\
\hline Proteinase $\mathrm{K}$ &
\end{tabular}

${ }^{1}$ Growth of L. monocytogenes EGDe in plate count broth supplemented with $3 \%$ sodium chloride with the addition of enzymes resulted in $10^{9} \mathrm{cfu} / \mathrm{mL}$ (data not shown). Results of a representative experiment are given.

The serially 2-fold diluted CFS of consortia I and II, inoculated with $10^{3} \mathrm{cfu} / \mathrm{mL}$ of Listeria, exhibited different bactericidal potentials, with CFS I clearly being more active (Figure 2, open symbols). Also, CFS I was more active when a kinetics of inhibition of $10^{7} \mathrm{cfu} /$ $\mathrm{mL}$ of Listeria was measured (Figure 2, filled symbols). In addition, supernatants I and II differed in other respects. Whereas boiling did not affect the antilisterial potential of CFS I, it abolished the bactericidal, but not the bacteriostatic, effect of CFS II, suggesting a mixture of active components. Upon autoclaving, CFS I maintained a bacteriostatic action, whereas in CFS II, inhibition of listerial growth was almost completely abolished. A treatment with proteinase K left CFS I unaffected, indicating the involvement of nonpeptide molecules, whereas CFS II was partially susceptible to proteinase $\mathrm{K}$, indicating the participation of a proteinaceous compound (results summarized in Table 1).

The inhibitory spectrum of both consortia was unexpectedly broad (Table 2), comprising L. monocytogenes isolates of 4 different serovars $(1 / 2 \mathrm{a}, 1 / 2 \mathrm{~b}, 3 \mathrm{a}$, and 4b), Bacillus spp., Staphylococcus aureus, as well as the gram-negative bacteria Salmonella enterica Typhimurium and Escherichia coli DH5a. Whereas bacteria exposed to CFS I were often killed within $6 \mathrm{~h}$, CFS II acted bacteriostatically and displayed a bactericidal action only after $24 \mathrm{~h}$ (data not shown). Taken together, these features indicate that heat-stable molecules with a broadband antagonistic activity were produced during propagation of the complex consortia.

\section{Distinct Shifts of Biodiversity upon Cultivation in Liquid Medium}

A taxonomic analysis of both consortia was conducted using Fourier transform infrared spectroscopy (Wenning et al., 2006). Both consortia grown on the cheese surface showed a high biodiversity (Figure 3, gray bars). Forty- 


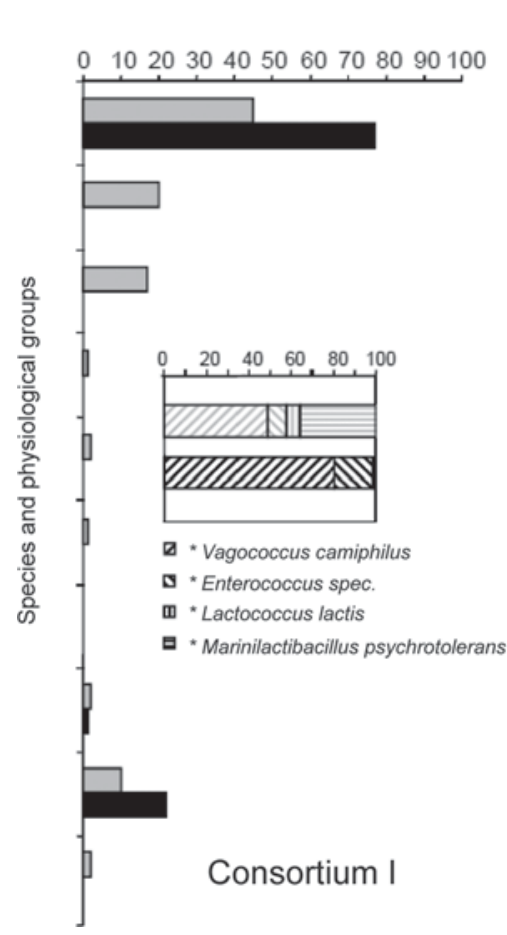

Number of isolates, \%

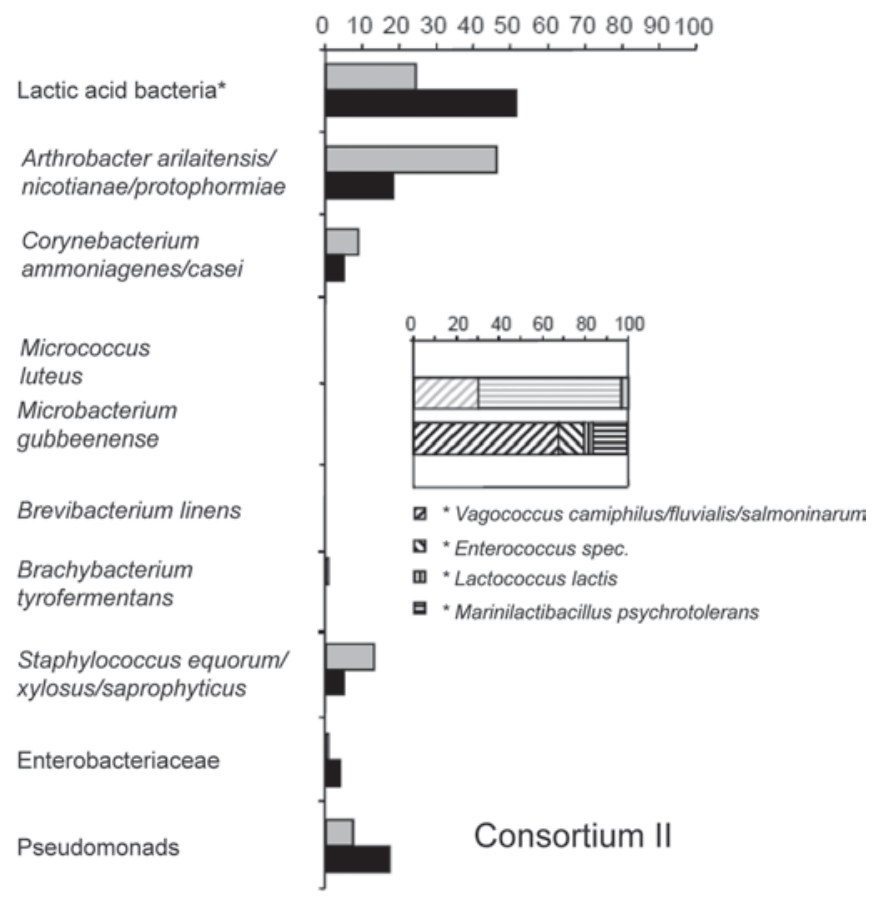

Figure 3. Biodiversity of consortia I and II. Gray bars indicate the original species composition, and black bars reflect the composition after $8 \mathrm{~h}$ of incubation in broth. The identities of 100 isolates per consortium and per time point were analyzed. The insets show the composition of the lactic acid bacteria.

eight strains of different physiological groups could be distinguished in consortium I, with $45 \%$ belonging to the LAB, $43 \%$ to coryneform species, and $12 \%$ to gramnegative enterobacteria and pseudomonads. Consortium II was composed of 46 different strains, with $69 \%$ belonging to the coryneform bacteria, $24 \%$ to the LAB, and $8 \%$ to the gram-negative bacteria. Arthrobacter, Corynebacterium, and Staphylococcus species were represented in high numbers. Gram-negative bacteria have been shown to constitute an important group in ripening consortia of Irish and French smear cheeses (Feurer et al., 2004; Mounier et al., 2005). Compared with recent biodiversity studies (Maoz et al., 2003; Rea et al., 2007), the high number of LAB in the surface consortium is unusual. This may be due to some carryover of LAB from the cheese matrix during sampling of microbial consortia.

The initial composition of the consortia changed considerably upon the 8-h cultivation in broth (Figure 3, black bars). The coryneform bacteria, which constituted

Table 2. Viable cell counts after $24 \mathrm{~h}$ of gram-positive and gram-negative indicator strains cultured in cell-free supernatants (CFS) I and $\mathrm{II}^{1}$

\begin{tabular}{llccc}
\hline Indicator strain & Serovar & CFS I & CFS II & PC3+ broth $^{2}$ \\
\hline Listeria monocytogenes EGDe & $1 / 2 \mathrm{a}$ & 0 & 0 & $1.1 \times 10^{9}$ \\
L. monocytogenes WSLC 1416 & $1 / 2 \mathrm{a}$ & 0 & $7.1 \times 10^{2}$ & $1.6 \times 10^{8}$ \\
L. monocytogenes WSLC 1499 & $1 / 2 \mathrm{~b}$ & 0 & $1.2 \times 10^{3}$ & $3.4 \times 10^{8}$ \\
L. monocytogenes WSLC 11149 & $3 \mathrm{a}$ & 0 & $7.6 \times 10^{2}$ & $5.3 \times 10^{8}$ \\
L. monocytogenes WSLC 1364 & $4 \mathrm{~b}$ & 0 & $1.8 \times 10^{3}$ & $5.5 \times 10^{8}$ \\
Staphylococus aureus ATCC 12600 & & 0 & 0 & $2.1 \times 10^{9}$ \\
Bacillus megaterium WS 1537 & Emetic & 0 & 0 & $1.1 \times 10^{9}$ \\
Bacillus cereus F4810/72 & Nonemetic & 0 & $2.3 \times 10^{1}$ & $3.9 \times 10^{8}$ \\
Bacillus cereus ATCC 10987 & Typhimurium & 0 & 0 & $3.7 \times 10^{8}$ \\
Salmonella enterica ATCC 14028 & & 0 & 0 & $2.5 \times 10^{9}$ \\
Escherichia coli DH5 ATCC PTA-1798 & & & & $1.1 \times 10^{8}$ \\
\hline
\end{tabular}

${ }^{1}$ Results of a representative experiment are given.

${ }^{2}$ Plate count broth supplemented with $3 \%$ sodium chloride. 
the predominant group in the smear, did not multiply or even disappeared, whereas the growth of gram-negative bacteria and LAB was favored, resulting in a doubling of their numbers. Taking into account that all isolates with less than $1 \%$ of the total cell count are below the detection limit of the method, the biodiversity in broth after an 8-h incubation is very different compared with the original diversity in the smear. Similar data were reported by Monnet et al. (2010), who performed successive propagations of 14 cheese-surface consortia on model cheese. An increase of the antilisterial potential was reported after repeated inoculation of the consortia on the cheese, concomitant with an increase of LAB and gram-negative cell counts. Therefore, we suggest that coryneform bacteria did not produce the inhibitory substances. Rather, the inhibition observed was thought to be due to bacteriocin production of the LAB.

\section{Detection of Bacteriocin Genes by PCR and Isolation of Antilisterial LAB}

The presence of genes encoding bacteriocins was explored by a PCR-based screening using genomic DNA, extracted directly from microbial consortia frozen in glycerol, as a template. Polymerase chain reactions for consortium I yielded positive results for genes encoding lactococcin $\mathrm{G}$, helveticin $\mathrm{J}$, and curvacin $\mathrm{A}$. For consortium II, amplification of genes encoding helveticin J, acidocin B, and cytolysin was successful. The in situ expression of the bacteriocin genes detected in consortia I and II could not be proven using total RNA extracts of 8-h liquid culture microbiota in PCR (data not shown).

Therefore, a large-scale screening for antilisterial $\mathrm{LAB}$ was performed using anaerobic incubation on all purpose tween agar. Among $776 \mathrm{LAB}$ colonies of the 8-h propagated consortium I, only 25 antilisterial colonies were found, comprising 4 different strains identified as Lactococcus lactis or Lactococcus lactis lactis. No Lactobacillus curvatus (producer of curvacin A) or Lactobacillus helveticus (producer of helveticin J) was identified, and amplification of lactococcin $\mathrm{G}$ was not successful in L. lactis strains. Among 889 isolates of consortium II, 92 colonies showed clearing zones in the first test. Seven different strains belonging to L. lactis or L. lactis lactis (3), Enterococcus faecalis (3), and Enterococcus durans (1) could be distinguished, one L. lactis being identical to a strain found in consortium I. Neither L. helveticus nor Lactobacillus acidophilus (producer of acidocin B) was found, nor was PCR detection of cytolysin possible in the E. faecalis strains.

The inhibitory phenotype of the LAB on solid medium was unstable. Clearing zones became smaller or even disappeared when producer strains were propagated. Bacteriocin-sensitive bacteria acting as environmental stimuli inducing bacteriocin production were previously reported (Maldonado et al., 2004; Rojo-Bezares et al., 2007). Most bacteriocin producers have been isolated from sources that contain a heterogeneous microflora, and bacteriocin expression is often regulated via a quorum-sensing mechanism mediated by peptide pheromones (Kleerebezem, 2004; Navarro et al., 2008). It is possible that the high cell density and the mixed culture during CFS production triggered bacteriocin production in some strains, but upon withdrawal of concomitant cells, the external stimulus of the signal cascade was eliminated and bacteriocin gene expression ceased.

Bacteriocins belonging to class I (e.g., cytolysin) and class II (as curvacin A, acidocin B, and lactococcin G) generally are resistant to heat (Nes et al., 2007) but lose their activity upon treatment with proteinase $\mathrm{K}$ (Contreras et al., 1997; Noonpakdee et al., 2003; Yamamoto et al., 2003). Helveticin J as a member of class III bacteriocins is sensitive to both heat and proteolytic enzymes (Joerger and Klaenhammer, 1986). Proteinase $\mathrm{K}$ and heating to $100^{\circ} \mathrm{C}$ decreased the inhibitory activity of CFS II at least partly, which may indicate that bacteriocins could be responsible for part of the inhibition observed. However, CFS I remained active after proteinase $\mathrm{K}$ addition, suggesting that substances different from bacteriocins are involved in the strong listericidal effect. Therefore, supernatant I was further investigated.

\section{Partial Purification of Inhibitory Fractions from CFS I}

The complex supernatant of consortium I was separated into 6 fractions (S1-S6) using SPE on RP-18 columns. The inhibitory activity was eluted with 20 and $40 \%$ methanol (S2 and S3, respectively), indicating the presence of polar substances. Subsequently, S2 was separated by RP-HPLC (Figure 1). Activity was recovered from fractions $\mathrm{H} 3$ and $\mathrm{H} 8$, with $\mathrm{H} 8$ having the greatest inhibitory potential against L. monocytogenes EGDe in the cultivation assay (Figure 1, inset). Compared with the native CFS I, fraction $\mathrm{H} 8$ displayed an antilisterial activity of only $90 \%$, reducing the initial $10^{3} \mathrm{cfu} / \mathrm{mL}$ to $10^{2} \mathrm{cfu} / \mathrm{mL}$ after $24 \mathrm{~h}$. The cause of the decrease in activity is unknown. We can possibly exclude denaturation of inhibitory proteins because the inhibitory potential of native CFS I was destroyed neither by addition of $30 \%$ methanol nor by freeze-drying and it was stable over a period of $3 \mathrm{yr}$ at $-20^{\circ} \mathrm{C}$ (data not shown). The use of SPE cartridges and HPLC columns with pore sizes of $100 \AA$ further cast doubt on the involvement of proteins in the active fractions. Our 
data indicate a mixture of substances being present in $\mathrm{H} 3$ and H8. At this state, fractions are far too complex for direct peptide sequencing. Short-chain fatty acids (Caplice and Fitzgerald, 1999) or antibacterial peptides (López-Expósito et al., 2006) might be involved in this inhibition.

\section{CONCLUSIONS}

Intrinsic microbial food protection, often mediated by bacteriocinogenic starter cultures, becomes more important with increasing consumer awareness of genetically modified organisms and questionable additives. In the present study, production of potent inhibitory substances by 2 cheese ripening consortia in an 8-h liquid culture was monitored. While culturing, the consortia underwent a significant microbial succession. However, the antagonistic potential of these substances against gram-negative bacteria and their resistance to proteinase $\mathrm{K}$ distinguishes them from classical bacteriocins. A preliminary characterization of the inhibitory substances was achieved through fractionation of the complex CFS I. Further research is needed to identify these substances and their producers and to figure out a potential antagonistic function in situ in cheese microbial consortia.

\section{ACKNOWLEDGMENTS}

This study received research funding from the European Community's Sixth Framework Programme. TRUEFOOD (Traditional United European Food) is an Integrated Project financed by the European Commission under the Sixth Framework Programme for Research and Technological Development (contract number FOOD-CT-2006-016264). The information in this document reflects only the authors' views, and the Community is not liable for any use that may be made of the information contained herein.

\section{REFERENCES}

Caplice, E., and G. F. Fitzgerald. 1999. Food fermentations: Role of microorganisms in food production and preservation. Int. J. Food Microbiol. 50:131-149.

Contreras, B. G., L. De Vuyst, B. Devreese, K. Busanyova, J. Raymaeckers, F. Bosman, E. Sablon, and E. J. Vandamme. 1997. Isolation, purification, and amino acid sequence of lactobin A, one of the two bacteriocins produced by Lactobacillus amylovorus LMG P-13139. Appl. Environ. Microbiol. 63:13-20.

Cotter, P. D., C. Hill, and R. P. Ross. 2005. Bacteriocins: Developing innate immunity for food. Nat. Rev. Microbiol. 3:777-788.

de Valk, H., C. Jacquet, V. Goulet, V. Vaillant, A. Perra, F. Simon, J. C. Desenclos, and P. Martin. 2005. Surveillance of Listeria infections in Europe. Euro Surveill. 10:251-255.

DIN EN ISO 11290-1. 2006. Detection of Listeria, § 64 Lebensmittelund Futtermittelgesetzbuch (LFGB), version from 26 April 2006. Deutsches Institut für Normung, Berlin, Germany.
Eppert, I., N. Valdes-Stauber, H. Götz, M. Busse, and S. Scherer. 1997. Growth reduction of Listeria spp. caused by undefined industrial red smear cheese cultures and bacteriocin-producing Brevibacterium linens as evaluated in situ on soft cheese. Appl. Environ. Microbiol. 63:4812-4817.

Farber, J. M., and P. I. Peterkin. 1991. Listeria monocytogenes, a foodborne pathogen. Microbiol. Rev. 55:476-511.

Feurer, C., T. Vallaeys, G. Corrieu, and F. Irlinger. 2004. Does smearing inoculum reflect the bacterial composition of the smear at the end of the ripening of a French soft, red-smear cheese? J. Dairy Sci. 87:3189-3197.

Freitag, N. E., G. C. Port, and M. D. Miner. 2009. Listeria monocytogenes-From saprophyte to intracellular pathogen. Nat. Rev. Microbiol. 7:623-628.

Goerges, S., J. Mounier, M. C. Rea, R. Gelsomino, V. Heise, R. Beduhn, T. M. Cogan, M. Vancanneyt, and S. Scherer. 2008. Commercial ripening starter microorganisms inoculated into cheese milk do not successfully establish themselves in the resident microbial ripening consortia of a South German red smear cheese. Appl. Environ. Microbiol. 74:2210-2217.

González-Fandos, E., and J. L. Dominguez. 2006. Efficacy of lactic acid against Listeria monocytogenes attached to poultry skin during refrigerated storage. J. Appl. Microbiol. 101:1331-1339.

Jack, R. W., J. R. Tagg, and B. Ray. 1995. Bacteriocins of grampositive bacteria. Microbiol. Rev. 59:171-200.

Jacquet, C., J. Rocourt, and A. Reynaud. 1993. Study of Listeria monocytogenes contamination in a dairy plant and characterization of the strains isolated. Int. J. Food Microbiol. 20:13-22.

Joerger, M. C., and T. R. Klaenhammer. 1986. Characterization and purification of helveticin $\mathrm{J}$ and evidence for a chromosomally determined bacteriocin produced by Lactobacillus helveticus 481. J. Bacteriol. 167:439-446.

Kleerebezem, M. 2004. Quorum sensing control of lantibiotic production; nisin and subtilin autoregulate their own biosynthesis. Peptides 25:1405-1414.

Kümmerle, M., S. Scherer, and H. Seiler. 1998. Rapid and reliable identification of food-borne yeasts by Fourier-transform infrared spectroscopy. Appl. Environ. Microbiol. 64:2207-2214.

Loessner, M., S. Guenther, S. Steffan, and S. Scherer. 2003. A pediocin-producing Lactobacillus plantarum strain inhibits Listeria monocytogenes in a multispecies cheese surface microbial ripening consortium. Appl. Environ. Microbiol. 69:1854-1857.

Loncarevic, S., M. L. Danielsson-Tham, and W. Tham. 1995. Occurrence of Listeria monocytogenes in soft and semi-soft cheeses in retail outlets in Sweden. Int. J. Food Microbiol. 26:245-250.

López-Expósito, I., F. Minervini, L. Amigo, and I. Recio. 2006. Identification of antibacterial peptides from bovine $\kappa$-casein. J. Food Prot. 69:2992-2997.

Low, J. C., and W. Donachie. 1997. A review of Listeria monocytogenes and listeriosis. Vet. J. 153:9-29.

Maldonado, A., R. Jimenez-Diaz, and J. L. Ruiz-Barba. 2004. Induction of plantaricin production in Lactobacillus plantarum NC8 after coculture with specific gram-positive bacteria is mediated by an autoinduction mechanism. J. Bacteriol. 186:1556-1564.

Maoz, A., R. Mayr, and S. Scherer. 2003. Temporal stability and biodiversity of two complex antilisterial cheese-ripening microbial consortia. Appl. Environ. Microbiol. 69:4012-4018.

McAuliffe, O., C. Hill, and R. P. Ross. 1999. Inhibition of Listeria monocytogenes in cottage cheese manufactured with a lacticin 3147-producing starter culture. J. Appl. Microbiol. 86:251-256.

Monnet, C., A. Bleicher, K. Neuhaus, A. S. Sarthou, M. N. LeclercqPerlat, and F. Irlinger. 2010. Assessment of the anti-listerial activity of microfloras from the surface of smear-ripened cheeses. Food Microbiol. 27:302-310.

Mounier, J., R. Gelsomino, S. Goerges, M. Vancanneyt, K. Vandemeulebroecke, B. Hoste, S. Scherer, J. Swings, G. F. Fitzgerald, and T. M. Cogan. 2005. Surface microflora of four smear-ripened cheeses. Appl. Environ. Microbiol. 71:6489-6500.

Navarro, L., B. Rojo-Bezares, Y. Sáenz, L. Díez, M. Zarazaga, F. RuizLarrea, and C. Torres. 2008. Comparative study of the pln locus of 
the quorum-sensing regulated bacteriocin-producing L. plantarum J51 strain. Int. J. Food Microbiol. 128:390-394.

Nes, I. F., D. B. Diep, and H. Holo. 2007. Bacteriocin diversity in Streptococcus and Enterococcus. J. Bacteriol. 189:1189-1198.

Noonpakdee, W., C. Santivarangkna, P. Jumriangrit, K. Sonomoto, and S. Panyim. 2003. Isolation of nisin-producing Lactococcus lactis WNC 20 strain from nham, a traditional Thai fermented sausage. Int. J. Food Microbiol. 81:137-145.

O'Sullivan, L., E. B. O'Connor, R. P. Ross, and C. Hill. 2006. Evaluation of live-culture-producing lacticin 3147 as a treatment for the control of Listeria monocytogenes on the surface of smear-ripened cheese. J. Appl. Microbiol. 100:135-143.

Oberreuter, H., H. Seiler, and S. Scherer. 2002. Identification of coryneform bacteria and related taxa by Fourier-transform infrared (FTIR) spectroscopy. Int. J. Syst. Evol. Microbiol. 52:91-100.

Rea, M. C., S. Gorges, R. Gelsomino, N. M. Brennan, J. Mounier, M. Vancanneyt, S. Scherer, J. Swings, and T. M. Cogan. 2007. Stability of the biodiversity of the surface consortia of Gubbeen, a red-smear cheese. J. Dairy Sci. 90:2200-2210.

Rojo-Bezares, B., Y. Sáenz, L. Navarro, M. Zarazaga, F. Ruiz-Larrea, and C. Torres. 2007. Coculture-inducible bacteriocin activity of Lactobacillus plantarum strain J23 isolated from grape must. Food Microbiol. 24:482-491.

Romanova, N., S. Favrin, and M. W. Griffiths. 2002. Sensitivity of Listeria monocytogenes to sanitizers used in the meat processing industry. Appl. Environ. Microbiol. 68:6405-6409.
Rudolf, M., and S. Scherer. 2001. High incidence of Listeria monocytogenes in European red smear cheese. Int. J. Food Microbiol. 63:91-98.

Saubusse, M., L. Millet, C. Delbès, C. Callon, and M. C. Montel. 2007. Application of single strand conformation polymorphismPCR method for distinguishing cheese bacterial communities that inhibit Listeria monocytogenes. Int. J. Food Microbiol. 116:126135

Tindall, B. J., E. Brambilla, M. Steffen, R. Neumann, R. Pukall, R. M. Kroppenstedt, and E. Stackebrandt. 2000. Cultivable microbial biodiversity: Gnawing at the Gordian knot. Environ. Microbiol. $2: 310-318$.

Valdes-Stauber, N., H. Götz, and M. Busse. 1991. Antagonistic effect of coryneform bacteria from red smear cheese against Listeria species. Int. J. Food Microbiol. 13:119-130.

Valdes-Stauber, N., and S. Scherer. 1994. Isolation and characterization of Linocin M18, a bacteriocin produced by Brevibacterium linens. Appl. Environ. Microbiol. 60:3809-3814.

Wenning, M., V. Theilmann, and S. Scherer. 2006. Rapid analysis of two food-borne microbial communities at the species level by Fourier-transform infrared microspectroscopy. Environ. Microbiol. 8:848-857.

Yamamoto, Y., Y. Togawa, M. Shimosaka, and M. Okazaki. 2003. Purification and characterization of a novel bacteriocin produced by Enterococcus faecalis strain RJ-11. Appl. Environ. Microbiol. 69:5746-5753. 